\title{
Postharvest Handling Practices and Treatment Methods for Tomato Handlers in Developing Countries: A Mini Review
}

\author{
Isaac Kojo Arah, ${ }^{1}$ Gerald K. Ahorbo, ${ }^{1}$ Etornam Kosi Anku, ${ }^{1}$ \\ Ernest Kodzo Kumah, ${ }^{1}$ and Harrison Amaglo ${ }^{2}$ \\ ${ }^{1}$ Department of Agro-Enterprise Development, Ho Polytechnic, P.O. Box HP 217, Ho, Ghana \\ ${ }^{2}$ Department of Agricultural Engineering, Ho Polytechnic, P.O. Box HP 217, Ho, Ghana \\ Correspondence should be addressed to Isaac Kojo Arah; isaacarah@gmail.com
}

Received 15 March 2016; Accepted 20 April 2016

Academic Editor: Pia Parolin

Copyright (C) 2016 Isaac Kojo Arah et al. This is an open access article distributed under the Creative Commons Attribution License, which permits unrestricted use, distribution, and reproduction in any medium, provided the original work is properly cited.

Tomato production has increased in recent years due to the economic and nutritional importance of the crop. This increase is made possible by the numerous research advances made along the entire value chain. However, scientific research has been focussed mainly on production whilst neglecting postharvest issues. Tomato producers have therefore enjoyed good harvests in recent times, though the good harvests of those from developing countries do not translate into profit as most are lost after harvest. From this study, it was revealed that the postharvest quality and shelf life of the fruit in part will depend on some postharvest handling practices and treatments carried out after harvest. Handling practices like harvesting, precooling, cleaning and disinfecting, sorting and grading, packaging, storing, and transportation played an important role in maintaining quality and extending shelf life. Using appropriate postharvest treatments like refrigeration, heat treatment, modified atmosphere packaging (MAP), and 1-methylcyclopropene (1-MCP) and calcium chloride $\left(\mathrm{CaCl}_{2}\right)$ application was also vital. It was concluded by this study that the quality of the harvested fruit can be maintained and shelf life extended by using appropriate postharvest handling practices and treatment methods. Failure to adhere to these practices will result in a high amount of loss.

\section{Introduction}

Tomato (Solanum lycopersicum L.) is one of the most widely cultivated and extensively consumed horticultural crops globally [1]. Although the crop is believed to have been originated from the wild in Peru, Ecuador, and other parts of tropical Americas [2], the nutritional and economic importance of the crop has led to its global production. By weight, tomatoes rank second only to potatoes in global production of all horticultural produce [3]. Tomato can be eaten in various ways and in a countless number of dishes. It can be eaten raw in salads or as an extract or sauce in many dishes and in drinks [4]. Tomato and tomato-based foods provide a wide variety of nutrients and many healthrelated benefits to the body [5]. Tomato contains higher amounts of lycopene, a type of carotenoid with antioxidant properties [6] which is beneficial in reducing the incidence of some chronic diseases [7] like cancer and many other cardiovascular disorders [8]. In regions where it is being cultivated and consumed, it constitutes a very essential part of the people's diet. The numerous uses of tomatoes can be a contributing factor to its widespread production. Tomato production has increased in recent years to about 163 million tonnes by 2013 [9] due to the economic and nutritional importance of the crop. This increase according to Alonso et al. [10] is made possible by the numerous research advances along the entire value chain. However, scientific research has focussed on production mainly whilst neglecting postharvest issues. Kader [11] reported that less than $5 \%$ of resource allocation in agricultural research in developing countries is on postharvest. This means more than $95 \%$ of resource allocation is on production. Research in the production aspect of the entire value chain in tomato production has resulted in improved cultivars or varieties which are high yielding and resistant to both diseases and drought. This has made tomato producers enjoy good harvests in recent years; however, the 
good harvest of many producers in developing countries does not translate into profit as most are lost after harvest. Postharvest loss is a major challenge hampering tomatoes production in most developing countries [12]. Tomato being a perishable crop as a result of its high moisture content has short shelf life of about 48 hours [13] under tropical conditions. Specialised postharvest handling practices and treatment methods are needed in order to extend the shelf life of the crop after harvest. Failure to adhere to these specialised handling practices and treatment methods will result in high amount of loss. Losses of up to $50 \%$ can be recorded in tomatoes between the harvesting and consumption stages of the distribution chain in tropical countries [11, 14] which is in line with estimates by Gustavo et al. [15] that between 49 and $80 \%$ of all agricultural commodities end up with the consumer whilst the remainder is lost. It is therefore important to know the appropriate handling practices and treatment methods needed for harvested tomatoes in order to reduce postharvest losses thereby increasing profitability for handlers in developing countries. The purpose of this paper therefore is to look at some postharvest handling practices and treatment methods that can be used by handlers of developing countries and how they can affect the postharvest qualities and shelf life of harvested tomatoes.

\section{Some Postharvest Handling Practices for Tomatoes}

Physical handling can have a drastic effect on the postharvest quality and shelf life of most harvested fruits and vegetables. For instance, rough handling during harvesting and after harvesting can cause mechanical injuries which can affect the postharvest quality and shelf life of harvested fruit like tomatoes [16]. It is therefore important to know suitable postharvest handling practices needed to maintain the quality and extend the shelf life of harvested tomatoes for producers in developing countries. Some of the handling practices which include harvesting, precooling, cleaning and disinfecting, sorting and grading, packaging, transportation, and storage are discussed below.

2.1. Harvesting. The physiological maturity of any fruit at harvest has an important effect on postharvest quality of that fruit [17]. Therefore, care must be taken as to when to harvest the fruit in order to attain the best quality. The shelf life of fruits and vegetables is described by postharvest physiologists in three stages: the maturation, ripening, and senescence stages. The maturation stage gives an indication of the fruit being ready for harvest [18]. Tomatoes can be harvested in either matured green, partially ripe, or ripe state. Tomato being a climacteric fruit can be harvested at the matured green state allowing ripening and senescence to occur during the postharvest period of the fruit. Producers targeting distant markets must harvest their tomatoes in a matured green state [19]. Harvesting tomatoes in matured green state will not only give producers ample time to prepare the fruit for the market but also prevent mechanical injuries during harvesting. Unfortunately, most producers from developing countries especially those in Africa harvest tomatoes when they are partially or fully ripened [20]. Fully ripened tomatoes are susceptible to mechanical injuries during harvesting resulting in shorter shelf life [21, 22]. Care must therefore be taken when harvesting tomatoes in ripe state to avoid these injuries which will hasten deterioration. Also, the use of harvesting and packaging containers with sharp edges must be discouraged to prevent bruising and puncturing of the fruits. Harvesting of fruits should be done in either early or late hours of the day to avoid excessive field heat generation. The inability of producers to follow these simple but vital harvesting procedures coupled with some inefficiencies (like lack of ready market and processing facilities) in the entire value chain may explain the reasons why there are lots of losses in tomatoes harvested at fully ripened state in most developing countries. Access to ready market is a big challenge when dealing with highly perishable crops like tomatoes in most developing countries. This challenge can be attributed to many factors but the major factor is the pattern of production resulting in high gluts. In most developing countries, a greater proportion of tomato production is rain fed. This causes high peaks in production during the raining seasons which is always more than the local consumption of the crop. The problem is further compounded by the lack of processing facilities or equipment which can be used to process the crop into a more durable form for later use. Processing tomatoes into a more durable form will also serve as a means of value addition which will finally give a better market value for the crop. Producers from developed countries always have supply contracts with multinational supermarkets to supply tomatoes. For instance, Blush Tomatoes, a tomato producing company in Australia, supplies Coles and Woolworth supermarkets with tomatoes making access to market already predetermined [12]. In the case of producers in many developing countries, there is lack of communication between producers and consumers and also lack of market information [11]. This could be the main reason for the mismatch between production and available markets. Producers therefore have to sell their harvest at very low cost to prevent total loss.

2.2. Precooling after Harvest. Field heat is usually high and undesirable at harvesting stage of many fruits and vegetables and should be removed as quickly as possible before any postharvest handling activity [23]. Excessive field heat gives rise to an undesirable increase in metabolic activity and immediate cooling after harvest is therefore important [24]. Precooling minimises the effect of microbial activity, metabolic activity, respiration rate, and ethylene production [25], whilst reducing the ripening rate, water loss, and decay, thereby preserving quality and extending shelf life of harvested tomatoes [26]. The suitable temperature range of about $13-20^{\circ} \mathrm{C}$ for tomato handling can be attained either in the early hours of the morning or late in the evening $[27,28]$. Harvested fruit must be precooled to remove excessive field heat if harvested at times other than the recommended periods. A cheap but effective way of precooling harvested tomatoes for producers of developing countries can be by dipping fruits in cold water (hydrocooling) mixed with disinfectants such as 
thiabendazole and sodium hypochlorite if availability of clean water is not a challenge. This method is effective in removing field heat whilst reducing microbial loads on the harvested fruits. Tomato producers in developing countries especially those from Africa assemble their harvested produce under tree shade in an attempt to reduce field heat [29]. Tree shade, however, is not a reliable and effective way of reducing field heat in harvested produce. Arah et al. [12] therefore suggested that the adoption of a simple on-farm structure like a small hut made of thatch can be very beneficial in precooling of harvested tomatoes.

\subsection{Cleaning or Disinfecting. Proper hygiene is a major con-} cern to all produce handlers, because of not only postharvest diseases, but also incidence of food-borne illnesses that can be transmitted to consumers. According to a report by the Government of India [30], Salmonella, Cryptosporidium, Cyclospora, and hepatitis A virus are some examples of disease causing organisms that have been transmitted to consumers through fresh fruits and vegetables. Unfortunately, cleaning or disinfecting tomatoes after harvest is not a common practice for most tomatoes handlers in developing countries especially those from Africa. This practice may be attributed to either the unavailability of portable water at the production sites or the sheer ignorance of the practice. However, in places where water is not a constraint, the use of disinfectants in water either for washing or for cooling can reduce both postharvest and food-borne diseases in fruits and vegetables. The use of various disinfectants during postharvest treatment of tomatoes is well documented. For instance, sodium hypochlorite solution has been used to sterilise tomato fruits in order to reduce the incidence of fungal infection before any postharvest treatment was applied [31]. Dipping of tomato fruits in thiabendazole solution reduced the microbial load on the fruits [32]. Fruits and vegetables are usually treated with chlorinated water after washing to reduce the microbial load prior to packaging. Workneh et al. [33] indicate that anolyte water dipping disinfection of tomatoes not only reduced the microbial loads on the fruits but also maintained superior quality of tomatoes during storage. Disinfection can be used in conjunction with hydrocooling to achieve the purpose of reducing excessive field heat and reducing microbial infection at the same time.

2.4. Sorting and Grading. One of the most important processes in packaging and marketing of fruit and vegetables is sorting [34] and grading. Sorting is the removal of rotten, damaged, or diseased fruits from the healthy and clean ones. The damaged or diseased fruits can produce ethylene in substantial amounts which can affect the adjacent fruits [35]. Grading is also the process of categorising fruits and vegetables on the basis of colour, size, stage of maturity, or degree of ripening. The two processes are vital in maintaining postharvest shelf life and quality of harvested tomatoes. Sorting limits the spread of infectious microorganisms from bad fruits to other healthy fruits during postharvest handling of tomatoes. Grading also helps handlers to categorise fruits and vegetables in a given common parameter which enables easy handling. For instance, grading on the basis of colour or maturity stage will help eliminate overripe fruits which will easily produce ethylene to hasten the ripening process in the whole batch. Commercial tomato producers normally use sophisticated systems that require precise sorting and grading standards for their produce. Small-scale producers and retailers in developing countries in contrast may not use written down grading and sorting standards; however, the produce must still be sorted and sized to some degree before selling or processing it.

2.5. Packaging. Packaging is also one of the important aspects to consider in addressing postharvest losses in fruits and vegetables. It is enclosing food produce or product to protect it from mechanical injuries, tampering, and contamination from physical, chemical, and biological sources [36]. Packaging as a postharvest handling practice in tomato production is essential in putting the produce into sizeable portions for easy handling. However, using unsuitable packaging can cause fruit damage resulting in losses [37]. Some common packaging materials used in most developing countries include wooden crates, cardboard boxes, woven palm baskets, plastic crates, nylon sacks, jute sacks, and polythene bags [37]. Most of the abovementioned packaging materials do not give all the protection needed by the commodity. Whilst the majority of these packaging materials like the nylon sacks do not allow good aeration within the packaged commodity causing a build-up of heat due to respiration, others like the woven basket have rough surfaces and edges which cause mechanical injuries to the produce. The wooden crate and the woven palm basket are some of the common packaging materials used in many developing countries especially those in Africa for packaging tomatoes. The major shortcoming of the wooden crate is in its height which creates a lot of compressive forces on fruits located at the base of the crate [38]. These undesirable compressive forces cause internal injuries which finally result in reduced postharvest quality of the tomatoes [20]. There have been suggestions of modifying the wooden crate to make it more suitable for packaging tomatoes. Kitinoja [39] has therefore suggested that the depth of the crate should be reduced considerably to reduce the build-up of compressive forces which can cause mechanical injuries to fruits at the base of the crate after packaging. The palm woven baskets used by tomato handlers have sharp edges lining the inside which puncture or bruise the fruit when they are used. It has also been recommended by Idah et al. [37] that woven palm baskets should be woven with the smooth side of the material turned inward.

2.6. Storage. Tomato has very high moisture content and therefore is very difficult to store at ambient temperatures for a long time. Meanwhile, storage in the value chain is usually required to ensure uninterrupted supply of raw materials for processors. Storage extends the length of the processing season and helps provide continuity of product supply throughout the seasons. For short-term storage (up to a week), tomato fruits can be stored at ambient conditions [40] if there is enough ventilation to reduce the accumulation of heat from respiration. For longer-term storage, ripe 
tomatoes can be stored at temperatures of about $10-15^{\circ} \mathrm{C}$ and $85-95 \%$ relative humidity [41]. At these temperatures, both ripening and chilling injuries are reduced to the minimal levels. These conditions are also difficult to obtain in most tropical countries and therefore losses of appreciable quantities of harvested tomatoes have been reported $[11,14]$. This is consistent with the claim that the quality of tomato is compromised when exposed to high temperatures and high relative humidity [42]. Very low temperature storage too is detrimental to the shelf life and quality of many tropical fruits like tomatoes. For instance, refrigerating a tomato will reduce its flavour, a quality trait of tomatoes which is largely determined by the total soluble solids (TSS) and $\mathrm{pH}$ of the fruit [43]. An understanding of the correct temperature management during storage of tomatoes is vital in extending the shelf life of the fruit whilst maintaining fruit qualities. Tomatoes handlers in tropical countries can store tomatoes for short to intermediate time by using evaporative cooling system made from woven jute sacks.

2.7. Transportation. In most developing countries, the production sites for many tomato producers are far from the marketing centres and also inaccessible by road. Transporting harvested tomatoes to the market on such bad road network and the lack of proper transportation like refrigerated vans become a big challenge for both producers and distributors [44]. This challenge therefore causes unnecessary delays in getting the produce to the market. Meanwhile, any delay between harvest and consumption of tomatoes can result in losses [45]. Losses of up to about $20 \%$ are incurred by producers due to transportation delays [46]. Producers will therefore make use of any available means of transport for their produce without considering its appropriateness in order to avoid delays. Some modes of transportation include human labour, donkeys, public transport, rented trucks, busses, lorries, fuel tankers, articulator trucks, and pick-up vans $[37,47]$. However, the use of appropriate transportation for tomatoes is a major factor to consider in postharvest handling of the fruit. During transportation, the produce should be immobilised by proper packaging and stacking to avoid excessive movement or vibration. Vibration and impact during transportation as a result of undulations on roads are one of the major causes of postharvest losses to most fruits and vegetables especially tomatoes [37]. The bad nature of road networks in most developing countries therefore provides these unfavourable factors during transportation resulting in great losses. The wobbling nature of most of the vehicles coupled with the bad nature of roads causes a lot of mechanical damage to the produce before it reaches its destination. Handlers from developed countries on the other hand use refrigerated containers and trailers which travel on reasonably good roads. Transporting tomatoes in refrigerated trucks is not only convenient, but also effective in preserving the quality of fruits. However, both the initial investment and the operation costs of these vehicles are very high and beyond the affordable reach of most producers in developing countries. Handlers of developing countries therefore transport their produce using the most affordable mode of transport without considering the effect it will have on the postharvest quality of the produce. Even though handlers from developing countries may not have the capacity to use refrigerated trucks, they should be well educated on the consequences that any other transportation option they use may have on their produce.

\section{Postharvest Treatment Techniques for Tomatoes}

After harvesting, the tomato fruit still remains living and performs all functions of a living tissue [48]. However, the postharvest quality of the fruit at harvest cannot be enhanced by any postharvest technology but can only be maintained [49]. In order to maintain this quality, there are some postharvest treatment methods that have to be adhered to in order to achieve this goal. Below are some of the treatments methods that can be used for harvested tomatoes.

3.1. Refrigeration Storage. Refrigeration is one of the most effective methods of preserving the quality of many fruits and vegetables for several days $[32,50]$. Low temperature storage can protect nonappearance quality attributes like texture, nutrition, aroma, and flavour in many harvested fruits [51]. Tomato handlers have also used refrigeration storage for tomatoes in attempt to extend shelf life. However, some fruits and vegetables of tropical origin, like tomatoes, are sensitive to chilling injury when they are stored below their critical temperature of $10^{\circ} \mathrm{C}$ [52]. This shortcoming of refrigeration storage was reported by Lee et al. [53] and Babitha et al. [54] where low temperatures from refrigeration storage caused chilling injuries which resulted in pitting, uneven ripening, and fungal infestation of stored fruits. This gives an indication that refrigeration storage may not be the most effective method of storing tomatoes for a long period. Another challenge in using refrigeration storage in tomato handling in most developing countries is the huge initial cost which is beyond the reach of most of underresourced handlers. However, in situations where handlers can afford refrigeration storage and temperature regulation is possible, temperatures of about $10-15^{\circ} \mathrm{C}$ should be maintained to avoid chilling injuries [41]. In spite of the high cost of refrigeration, it is very important to control storage temperatures and relative humidity during storage, as these two parameters are the main causes of deterioration in fruits and vegetables. The required optimum temperatures of about $10-15^{\circ} \mathrm{C}$ and 85-95\% relative humidity [41] can be achieved by using less expensive methods of cooling such as evaporative cooling system as suggested by Workneh and Woldetsadik [55]. In such cooling system, air temperatures can be decreased to about $16^{\circ} \mathrm{C}$, whilst relative humidity can be increased to about $91 \%$, which is appropriate for reducing deterioration of harvested tomatoes due to physiological weight loss [56]. Evaporative coolers can be manufactured locally using low cost materials like jute sacks, wooden planks, and basins.

3.2. Postharvest Heat Treatment of Tomatoes. Postharvest heat treatment of fruits and vegetables is receiving more attention as a way of reducing the incidence of chilling 
injuries in temperature sensitive fruits of tropical origin. It is one of the approaches that can be used to avoid or reduce chilling injuries in stored fruits [57]. Postharvest heat treatments using hot air and heated water have been reported to reduce chilling injuries in fruits like mangoes, oranges, zucchini, and tomatoes [50]. Heat treating of tomato fruit at temperatures of about $37-42^{\circ} \mathrm{C}$ prior to cold storage can slow down ripening whilst increasing pathogenic resistance when in storage [58]. Some studies have shown that heat treatment prior to storage enhanced or caused no change in some quality traits of stored tomatoes. For instance, TSS of heat treated tomatoes was unaffected when tomatoes ripened at ambient temperatures [59] or when they ripened in a modified atmosphere storage system [60]. However, uniform heat treatment before cold storage at $14^{\circ} \mathrm{C}$ actually increased TSS and titratable acids (TA) when fruits ripened as compared to the untreated fruits [61]. In situations where refrigeration storage is possible, postharvest heat treatment of tomatoes can be used in conjunction with refrigeration storage in extending shelf life of harvested tomatoes.

3.3. Modified Atmosphere Packaging (MAP). Modified atmosphere packaging (MAP) refers to a packaging technique of using specialised materials in packaging products in a predetermined composition of gases which are mainly oxygen $\left(\mathrm{O}_{2}\right)$ and carbon dioxide $\left(\mathrm{CO}_{2}\right)$ after which there is no active effort of modifying the storage space [17]. The packaging materials used in MAP allow for diffusion of gases through them until a stable equilibrium is reached between the external gases and those inside the package [62]. The most commonly used MAP materials are polyethylene terephthalate (PET), low density polyethylene (LDP), high density polyethylene (HDP), polyvinyl chloride (PVC), polypropylene [63], polystyrene $[64,65]$, and some chemically modified derivatives [17]. The benefit of using MAP is not only in providing a modified atmosphere to control ripening [66], but also in reducing water loss in stored products [67], reducing mechanical injuries, and enhancing better hygiene which reduces the spread of food-borne diseases [66]. MAP creates water saturated or near-saturated atmosphere (high relative humidity) around the fruit which reduces water loss and shrinkage [32]. Water loss and subsequent shriveling of tomatoes in tropical regions are one of the causes of their deterioration. Fruit shriveling may become evident with any small percentage of moisture loss. The use of MAP by tomatoes handlers in developing countries will therefore prevent or reduce the problem of water loss in harvested tomatoes. However, maintaining excessively high level of relative humidity inside the package can result in moisture condensation on the commodity, which will in turn create conducive environment favourable for pathogenic activities thereby increasing the risk of fruit deterioration [60]. Tomato handlers must therefore be trained in the proper use of MAP for tomatoes to avoid moisture condensation which will result in fruit deterioration.

3.4. 1-Methylcyclopropene (1-MCP). The use of 1-methylcyclopropene (1-MCP) has been shown to suppress the action of ethylene in many fruits and vegetables [68]. The rate of ethylene production in harvested climacteric fruit like tomato is indicative of the metabolic activities within the fruit. The higher the metabolic activities within the harvested fruit, the shorter its shelf life. However, the aim of every postharvest technology is to slow down the metabolism in the harvested produce thereby increasing shelf life. The use of 1-MCP by handlers in developing countries is therefore essential in extending shelf life of harvested tomatoes. The use of 1-MCP has been shown to slow down many of the metabolic activities associated with the ripening process such as colour change, cell wall breakdown, and respiration rates making it a useful technique in extending storage life of fruits [69]. Although 1-MCP treatment preserves quality of fruits at advanced ripened stage, its application in green fruit may result in nonuniform ripening $[70,71]$. Storing green fruits using 1-MCP must therefore be done with caution in order to achieve full ripeness [72]. In postharvest tomato treatment in particular, 1-MCP has been shown to prolong the shelf life of fruits by retaining fruit firmness and delaying both lycopene accumulation and external colour development [68]. Another benefit of using 1-MCP in tomatoes is the prevention of abscission in fruits that are sold on the vine [73]. This will have a desirable photosynthetic effect in the vegetative tissues which could lead to uninterrupted supply of certain vital substances or nutrients to the fruit thereby increasing the consumption quality. Educating and training handlers on how use 1-MCP in tomatoes will help reduce some amount of postharvest loss associated with the crop.

3.5. Calcium Chloride $\left(\mathrm{CaCl}_{2}\right)$ Application. Postharvest calcium chloride $\left(\mathrm{CaCl}_{2}\right)$ application is receiving considerable attention in recent times due to its positive effects on shelf life whilst maintaining quality of many fruits and vegetables [74]. It has been found that calcium chloride delays ripening and senescence, reduces respiration, extends shelf life, maintains firmness, and reduces physiological disorders of many fruits and vegetables [75, 76]. Lester and Grusak [77] also noted that both pre- and postharvest calcium application delayed senescence in many fruits without any negative effect on consumer acceptability. For instance, a $1 \% \mathrm{CaCl}_{2}$ treatment was found to have reduced fungal attack, slowed down fruit ripening, and maintained structural integrity of cell walls of strawberry [78], whilst the same application also delayed softening and increased storage life by almost 3 months in Kiwi fruits stored at $0^{\circ} \mathrm{C}$ [79]. In loquat fruit, calcium chloride $\left(\mathrm{CaCl}_{2}\right)$ dip extended shelf life by $4-5$ weeks [76]. In tomatoes, calcium chloride treatment is vital for maintaining quality of fruits by reducing the physiological disorders, increasing the fruit firmness, delaying ripening process, and prolonging the shelf life [80]. $\mathrm{CaCl}_{2}$ has been found to have delayed fruit colour development in tomatoes and slowed down ethylene production thereby extending shelf life by $92 \%$ [74]. Also, fruits treated with $\mathrm{CaCl}_{2}$ have been shown to have reduced physiological weight loss and maintain higher firmness levels during storage [81]. Bhattarai and Gautam [82] also reported a reduction of physiological weight loss in tomatoes from $19 \%$ to $17 \%$ by using $0.25 \% \mathrm{CaCl}_{2}$ application for 10 -day storage. However, $\mathrm{CaCl}_{2}$ is a very cheap and soluble salt which can be dissolved into any concentration for use by producers. 
The affordable cost of the $\mathrm{CaCl}_{2}$ salt and the relatively easy preparation of the solution and its application therefore make it a favourable choice for adoption by underresourced handlers of developing countries in reducing postharvest losses in tomatoes. A simple and cost-effective way of using $\mathrm{CaCl}_{2}$ is by adding the required dosage of the salt in water used for precooling or cleaning of the fruits after harvesting.

\section{Conclusion}

The postharvest quality status and shelf life of the fruits in part will depend on some postharvest handling practices and treatments carried out after harvest. Even though the quality of any fruit after harvest cannot be improved by the use of any postharvest handling practices or treatment methods, it can however be maintained. Shelf life of the fruit can also be extended when appropriate postharvest handling practices and treatment methods are employed. Failure to adhere to these best practices has resulted in high amount of loss especially in developing countries. Although most tomatoes handlers from developing countries may not have high-tech postharvest technologies in addressing postharvest losses in tomatoes, understanding simple and the best postharvest practices has been found to be beneficial. Postharvest handling practices like harvesting, precooling, cleaning or disinfecting, sorting and grading, packaging, storage, and transporting played an important role in maintaining quality and extending shelf life of the tomato fruits after harvest. Also, the use of appropriate postharvest treatment methods like refrigeration, postharvest heat treatment, modified atmosphere packaging (MAP), and 1-methylcyclopropene (1MCP) and calcium chloride $\left(\mathrm{CaCl}_{2}\right)$ application was also vital. It is concluded by this study that the quality of the harvested fruit can be maintained and shelf life extended by simply using appropriate postharvest handling practices and treatment methods. Until these simple postharvest practices are followed, postharvest losses in tomatoes will continue to be a major challenge for tomatoes handlers of developing countries.

\section{Competing Interests}

The authors declare that there are no competing interests regarding the publication of this paper.

\section{References}

[1] S. Grandillo, D. Zamir, and S. D. Tanksley, "Genetic improvement of processing tomatoes: a 20 years perspective," Euphytica, vol. 110, no. 2, pp. 85-97, 1999.

[2] C. M. Rick and L. Butler, "Cytogenetics of the tomato," Advances in Genetics, vol. 8, no. 1, pp. 267-382, 1956.

[3] H.-L. Tan, J. M. Thomas-Ahner, E. M. Grainger et al., "Tomatobased food products for prostate cancer prevention: what have we learned?" Cancer and Metastasis Reviews, vol. 29, no. 3, pp. 553-568, 2010.

[4] T. Alam and G. K. Goyal, "Packaging and storage of tomato puree and paste," Stewart Postharvest Review, vol. 3, no. 5, pp. $1-8,2007$.
[5] J. K. Willcox, G. L. Catignani, and S. Lazarus, "Tomatoes and cardiovascular health," Critical Reviews in Food Science and Nutrition, vol. 43, no. 1, pp. 1-18, 2003.

[6] L. Arab and S. Steck, "Lycopene and cardiovascular disease," The American Journal of Clinical Nutrition, vol. 71, no. 6, pp. 1691S1695S, 2000.

[7] A. Basu and V. Imrhan, "Tomatoes versus lycopene in oxidative stress and carcinogenesis: conclusions from clinical trials," European Journal of Clinical Nutrition, vol. 61, no. 3, pp. 295303, 2007.

[8] B. Burton-Freeman and K. Reimers, "Tomato consumption and health: emerging benefits," American Journal of Lifestyle Medicine, vol. 5, no. 2, pp. 182-191, 2011.

[9] FAOSTAT, Global Tomato Production in 2013, FAO, Rome, Italy, 2014.

[10] A. Alonso, S. García-Martínez, L. Vázquez-Araújo, J. J. Ruiz, and Á. A. Carbonell-Barrachina, "Comparative post-harvest behaviour of traditional and virus-resistant Muchamiel tomatoes," Journal of the Science of Food and Agriculture, vol. 90, no. 6, pp. 1056-1062, 2010.

[11] A. A. Kader, "Increasing food availability by reducing postharvest losses of fresh produce," Acta Horticulturae, vol. 682, no. 1, pp. 2169-2176, 2005.

[12] I. K. Arah, E. K. Kumah, E. K. Anku, and H. Amaglo, "An overview of post-harvest losses in tomato production in Africa: causes and possible prevention strategies," Journal of Biology, Agriculture and Healthcare, vol. 5, no. 16, pp. 78-88, 2015.

[13] R. H. Muhammad, E. Bamisheyi, and F. F. Olayemi, "The effect of stage of ripening on the shelf life of tomatoes (Lycopersicon esculentum) stored in the evaporative cooling system (E.C.S)," Journal of Dairying, Foods \& Home Sciences, vol. 30, no. 4, pp. 299-301, 2011.

[14] N. Pila, N. B. Gol, and T. V. R. Rao, "Effect of post harvest treatments on physicochemical characteristics and shelf life of tomato (Lycopersicon esculentum Mill.) fruits during storage," American-Eurasian Journal of Agricultural \& Environmental Science, vol. 9, no. 5, pp. 470-479, 2010.

[15] B. C. V. Gustavo, F. M. J. Juan, M. Stella, S. T. Maria, L. M. Aurelio, and W. C. Jorge, "Handling and preservation of fruits and vegetables by combined methods for rural areas," Technical Manual FAO Agricultural Services Bulletin 149, FAO, Rome, Italy, 2003.

[16] I. K. Arah, H. Amaglo, E. K. Kumah, and H. Ofori, "Preharvest and postharvest factors affecting the quality and shelf life of harvested tomatoes: a mini review," International Journal of Agronomy, vol. 2015, Article ID 478041, 6 pages, 2015.

[17] D. M. Beckles, "Factors affecting the postharvest soluble solids and sugar content of tomato (Solanum lycopersicum L.) fruit," Postharvest Biology and Technology, vol. 63, no. 1, pp. 129-140, 2012.

[18] FAO, Basic Harvest and Post-Harvest Handling Considerations for Fresh Fruits and Vegetableshandling and Preservation, FAO, Rome, Italy, 2008.

[19] K. M. Moneruzzaman, A. B. M. S. Hossain, W. Sani, M. Saifuddin, and M. Alenazi, "Effect of harvesting and storage conditions on the post harvest quality of tomato," Australian Journal of Crop Science, vol. 3, no. 2, pp. 113-121, 2009.

[20] I. K. Arah, "An overview of post-harvest challenges facing tomato production in Africa," in Africa: Diversity and Development, 37th AFSAAP Conference Proceedings, AFSAAP, pp. 1-21, The African Studies Association of Australasia and the 
Pacific, 2015, http://afsaap.org.au/assets/Arah-Isaac-Kojo.-Anoverview-of-post-harvest-challenges.pdf.

[21] C. B. Watkins, "The use of 1-methylcyclopropene (1-MCP) on fruits and vegetables," Biotechnology Advances, vol. 24, no. 4, pp. 389-409, 2006.

[22] P. M. A. Toivonen, "Fruit maturation and ripening and their relationship to quality," Stewart Postharvest Review, vol. 3, no. 2, 5 pages, 2007.

[23] J. Bachmann and R. Earles, Postharvest Handling of Fruits and Vegetables, Appropriate Technology Transfer for Rural Areas, Fayetteville, NC, USA, 2000.

[24] B. Akbudak, N. Akbudak, V. Seniz, and A. Eris, "Effect of preharvest harpin and modified atmosphere packaging on quality of cherry tomato cultivars 'Alona' and 'Cluster,' British Food Journal, vol. 114, no. 2, pp. 180-196, 2012.

[25] N. C. Shahi, U. C. Lohani, K. Chand, and A. Singh, "Effect of pre-cooling treatments on shelf life of tomato in ambient condition," International Journal of Food, Agriculture and Veterinary Sciences, vol. 2, no. 3, pp. 50-56, 2012.

[26] M. D. Ferreira, J. K. Brecht, S. A. Sargent, and J. J. Aracena, "Physiological responses of strawberry to film wrapping and precooling methods," Proceedings of the Florida State Horticultural Society, vol. 107, pp. 265-269, 1994.

[27] A. A. Kader, "Effects of postharvest handling procedures on tomato quality," in Symposium on Tomato Production on Arid Land 190, pp. 209-222, 1984.

[28] L. A. Risse, W. R. Miller, and R. E. McDonald, "Effects of film wrapping on mature green tomatoes before and after ethylene treatment," Proceedings of the Florida State Horticultural Society, vol. 97, pp. 112-114, 1984.

[29] F. F. Olayemi, J. A. Adegbola, E. I. Bamishaiye, and A. M. Daura, "Assessment of post-harvest challenges of small scale farm holders of tomotoes, bell and hot pepper in some local government areas of Kano State, Nigeria," Bayero Journal of Pure and Applied Sciences, vol. 3, no. 2, pp. 39-42, 2011.

[30] Government of India, "Estimation loss of horticulture produce due to non-availability of post harvest \& food processing facilities in Bihar \& Uttar Pradesh," Socio-Economic Research Planning Commission, ASET, New Delhi, India.

[31] T. Genanew, "Effect of post harvest treatments on storage behavior and quality of tomato fruits," World Journal of Agricultural Sciences, vol. 9, no. 1, pp. 29-37, 2013.

[32] A. Batu and A. Keith Thompson, "Effects of modified atmosphere packaging on post harvest qualities of pink tomatoes," Turkish Journal of Agriculture and Forestry, vol. 22, no. 4, pp. 365-372, 1998.

[33] T. S. Workneh, G. Osthoff, and M. Steyn, "Effects of preharvest treatment, disinfections, packaging and storage environment on quality of tomato," Journal of Food Science and Technology, vol. 49, no. 6, pp. 685-694, 2012.

[34] O. O. Arjenaki, P. A. Moghaddam, and A. M. Motlagh, "Online tomato sorting based on shape, maturity, size, and surface defects using machine vision," Turkish Journal of Agriculture and Forestry, vol. 37, no. 1, pp. 62-68, 2013.

[35] M. E. Saltveit, "Effect of ethylene on quality of fresh fruits and vegetables," Postharvest Biology and Technology, vol. 15, no. 3, pp. 279-292, 1999.

[36] P. Prasad and A. Kochhar, "Active packaging in food industry: a review," Journal of Environmental Science, Toxicology and Food Technology, vol. 8, no. 5, pp. 1-7, 2014.
[37] P. A. Idah, E. S. A. Ajisegiri, and M. G. Yisa, "Fruits and vegetables handling and transportation in Nigeria," AU Journal of Technology, vol. 10, no. 3, pp. 175-183, 2007.

[38] W. C. Hurst, "Harvest, handling and sanitation," in Commercial Tomato Production Handbook B 1312, CAES Publications, University of Georgia, 2010.

[39] L. Kitinoja, "Causes and sources of postharvest problems," Postharvest Training CDRom $\backslash$ Sample Presentations from Ghana, pp. 1-19, 2008.

[40] D. Znidarcic and T. Pozrl, "Comparative study of quality changes in tomato cv. Malike (Lycopersicon esculentum Mill) while stored at different temperatures," Acta Agriculturae Slovenica, vol. 87, no. 2, pp. 235-243, 2006.

[41] L. R. Castro, C. Vigneault, M. T. Charles, and L. A. B. Cortez, "Effect of cooling delay and cold-chain breakage on 'Santa Clara' tomato," Journal of Food, Agriculture \& Environment, vol. 3, no. 1, pp. 49-54, 2005.

[42] R. Parker and B. Maalekuu, "The effect of harvesting stage on fruit quality and shelf-life of four tomato cultivars (Lycopersicon esculentum Mill)," Agriculture and Biology Journal of North America, vol. 4, no. 3, pp. 252-259, 2013.

[43] C. L. Moretti, S. A. Sargent, D. J. Huber, A. G. Calbo, and R. Puschmann, "Chemical composition and physical properties of pericarp, locule, and placental tissues of tomatoes with internal bruising," Journal of the American Society for Horticultural Science, vol. 123, no. 4, pp. 656-660, 1998.

[44] O. A. Abimbola, "Post-harvest losses and welfare of tomato farmers in Ogbomosho, Osun state, Nigeria," Journal of Stored Products and Postharvest Research, vol. 5, no. 2, pp. 8-13, 2014.

[45] A. A. Kader, "Effects of postharvest handling procedures on tomato quality," Acta Horticulturae, vol. 190, pp. 209-222, 1986.

[46] L. A. Babatola, D. O. Ojo, and O. I. Lawal, "Effect of storage conditions on tomato (Lycopersicon esculentum Mili.) quality and shelf life," Journal of Biological Sciences, vol. 8, no. 2, pp. 490-493, 2008.

[47] H. Getinet, T. S. Workneh, and K. Woldetsadik, "Effect of maturity stages, variety and storage environment on sugar content of tomato stored in multiple pads evaporative cooler," African Journal of Biotechnology, vol. 10, no. 80, pp. 18481-18492, 2011.

[48] J. Joas and M. Léchaudel, "A comprehensive integrated approach for more effective control of tropical fruit quality," Stewart Postharvest Review, vol. 4, no. 2, pp. 1-14, 2008.

[49] M. Tigist, T. S. Workneh, and K. Woldetsadik, "Effects of variety on the quality of tomato stored under ambient conditions," Journal of Food Science and Technology, vol. 50, no. 3, pp. 477486, 2013.

[50] S. D. C. Rodriguez, B. López, and A. R. Chaves, "Effect of different treatments on the evolution of polyamines during refrigerated storage of eggplants," Journal of Agricultural and Food Chemistry, vol. 49, no. 10, pp. 4700-4705, 2001.

[51] R. E. Paull, "Effect of temperature and relative humidity on fresh commodity quality," Postharvest Biology and Technology, vol. 15, no. 3, pp. 263-277, 1999.

[52] J. K. Raison and J. M. Lyons, "Chilling injury: a plea for uniform terminology," Plant, Cell \& Environment, vol. 9, no. 9, pp. 685686, 1986.

[53] Y. S. Lee, J. N. Kim, and D. S. Chung, "The effect of 1-MCP (1-methylcyclopropene) treatment methods on the ripening process of tomato fruit during postharvest storage," Journal of Horticulture, Environment \& Biotechnology, vol. 4, no. 3, pp. 175-181, 2008. 
[54] K. C. Babitha, B. T. Ninganur, M. B. Chetti, D. I. Jirali, and S. I. Harlapur, "Effect harvest treatment and atorage conditions on physio-chemical parameters in extending shelf life in tomato," Plant Archhives, vol. 10, no. 1, pp. 37-47, 2010.

[55] T. S. Workneh and K. Woldetsadik, "Forced ventilation evaporative cooling: a case study on banana, papaya, orange, mandarin, and lemon," Tropical Agirculture, vol. 81, no. 1, pp. 1-6, 2004.

[56] T. S. Workneh, "Feasibility and economic evaluation of lowcostevaporative cooling system in fruit and vegetables storage," African Journal of Food, Agriculture, Nutrition and Development, vol. 10, no. 8, pp. 2984-2997, 2010.

[57] S. Lurie and J. D. Klein, "Ripening characteristics of tomatoes stored at $12^{\circ} \mathrm{C}$ and $2^{\circ} \mathrm{C}$ following a prestorage heat treatment," Journal of Horticultural Science, vol. 51, no. 1-2, pp. 55-64, 1992.

[58] B. Akbudak, N. Akbudak, V. Seniz, and A. Eris, "Sequential treatments of hot water and modified atmosphere packaging in cherry tomatoes," Journal of Food Quality, vol. 30, no. 6, pp. 896910, 2007.

[59] R. E. McDonald, T. G. McCollum, and E. A. Baldwin, "Temperature of water heat treatments influences tomato fruit quality following low-temperature storage," Postharvest Biology and Technology, vol. 16, no. 2, pp. 147-155, 1999.

[60] Suparlan and K. Itoh, "Combined Effects of Hot Water Treatment (HWT) and Modified Atmosphere Packaging (MAP) on quality of tomatoes," Packaging Technology and Science, vol. 16, no. 4, pp. 171-178, 2003.

[61] J. Lu, M. T. Charles, C. Vigneault, B. Goyette, and G. S. V. Raghavan, "Effect of heat treatment uniformity on tomato ripening and chilling injury," Postharvest Biology and Technology, vol. 56, no. 2, pp. 155-162, 2010.

[62] C. A. Phillips, "Review: modified atmosphere packaging and its effects on the microbiological quality and safety of produce," International Journal of Food Science and Technology, vol. 31, no. 6, pp. 463-479, 1996.

[63] H. P. J. De Wild, E. C. Otma, and H. W. Peppelenbos, "Carbon dioxide action on ethylene biosynthesis of preclimacteric and climacteric pear fruit," Journal of Experimental Botany, vol. 54, no. 387, pp. 1537-1544, 2003.

[64] F. Artés, P. A. Gómez, and F. Artés-Hernández, "Modified atmosphere packaging of fruits and vegetables," Stewart Postharvest Review, vol. 2, no. 5, pp. 1-13, 2006.

[65] Sandhya, "Modified atmosphere packaging of fresh produce: current status and future needs," LWT-Food Science and Technology, vol. 43, no. 3, pp. 381-392, 2010.

[66] A. A. Kader and C. B. Watkins, "Modified atmosphere packaging-toward 2000 and beyond," HortTechnology, vol. 10, no. 3, pp. 483-486, 2000.

[67] M. I. Cantwell, X. Nie, and G. Hong, "Impact of storage conditions on grape tomato quality," in Proceedings of the 6th ISHS Postharvest Symposium. International Society of Horticultural Sciences, Antalya, Turkey, 2009.

[68] M. Cliff, S. Lok, C. Lu, and P. M. A. Toivonen, "Effect of 1-methylcyclopropene on the sensory, visual, and analytical quality of greenhouse tomatoes," Postharvest Biology and Technology, vol. 53, no. 1-2, pp. 11-15, 2009.

[69] C. B. Watkins, "Overview of 1-methylcyclopropene trials and uses for edible horticultural crops," HortScience, vol. 43, no. 1, pp. 86-94, 2008.

[70] Y. Mostofi, P. M. A. Toivonen, H. Lessani, M. Babalar, and C. $\mathrm{Lu}$, "Effects of 1-methylcyclopropene on ripening of greenhouse tomatoes at three storage temperatures," Postharvest Biology and Technology, vol. 27, no. 3, pp. 285-292, 2003.
[71] B. M. Hurr, D. J. Huber, and J. H. Lee, "Differential responses in color changes and softening of 'Florida 47' tomato fruit treated at green and advanced ripening stages with the ethylene antagonist 1-methylcyclopropene," HortTechnology, vol. 15, no. 3, pp. 617-622, 2005.

[72] D. J. Huber, "Suppression of ethylene responses through application of 1-methylcyclopropene: a powerful tool for elucidating ripening and senescence mechanisms in climacteric and nonclimacteric fruits and vegetables," HortScience, vol. 43, no. 1, pp. 106-111, 2008.

[73] H. C. Passam, I. C. Karapanos, P. J. Bebeli, and D. Savvas, "A review of recent research on tomato nutrition, breeding and post-harvest technology with refrence to fruit quality," European Journal of Plant Science and Biotechnology, vol. 1, no. 1, pp. 1-21, 2007.

[74] P. Senevirathna and W. Daundasekera, "Effect of postharvest calcium chloride vacuum infiltration on the shelf life and quality of tomato (cv. 'Thilina')," Ceylon Journal of Science, vol. 39, no. 1, pp. 35-44, 2010.

[75] M. N. Hong, B. C. Lee, S. Mendonca, M. V. E. Grossmann, and R. Verhe, "Effect of infiltrated calcium on ripening of tomato fruits," LWT Journal of Food Science, vol. 33, pp. 2-8, 1999.

[76] A. Akhtar, N. A. Abbasi, and A. Hussain, "Effect of calcium chloride treatments on quality characteristics of loquat fruit during storage," Pakistan Journal of Botany, vol. 42, no. 1, pp. 181-188, 2010.

[77] G. E. Lester and M. A. Grusak, "Field application of chelated calcium: postharvest effects on cantaloupe and honeydew fruit quality," HortTechnology, vol. 14, no. 1, pp. 29-38, 2004.

[78] I. Lara, P. García, and M. Vendrell, "Modifications in cell wall composition after cold storage of calcium-treated strawberry (Fragaria x ananassa Duch.) fruit," Postharvest Biology and Technology, vol. 34, no. 3, pp. 331-339, 2004.

[79] D. Gerasopoulos and P. D. Drogoudi, "Summer-pruning and preharvest calcium chloride sprays affect storability and low temperature breakdown incidence in kiwifruit," Postharvest Biology and Technology, vol. 36, no. 3, pp. 303-308, 2005.

[80] N. A. Abbasi, L. Zafar, H. A. Khan, and A. Ahad Qureshi, "Effects of naphthalene acetic acid and calcium chloride application on nutrient uptake, growth, yield and post harvest performance of tomato fruit," Pakistan Journal of Botany, vol. 45, no. 5, pp. 1581-1587, 2013.

[81] M. Gharezi and M. Gharezi, "Effect of post harvest treatment on stored cherry tomatoes," Journal of Nutrition \& Food Sciences, vol. 2, no. 8, pp. 1-10, 2012.

[82] D. R. Bhattarai and D. M. Gautam, "Effect of harvesting method and calcium on post harvest physiology of tomato," Nepal Agriculture Research Journal, vol. 7, pp. 37-41, 2009. 


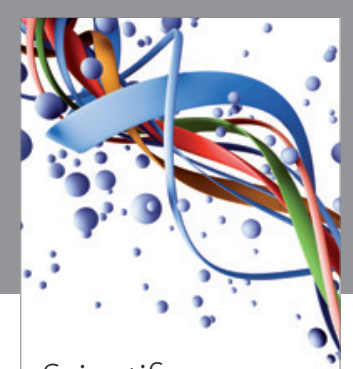

Scientifica
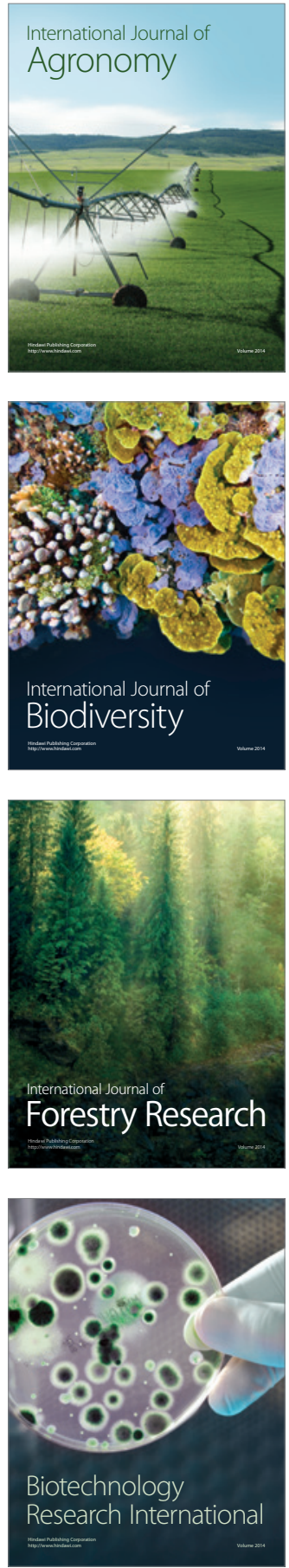
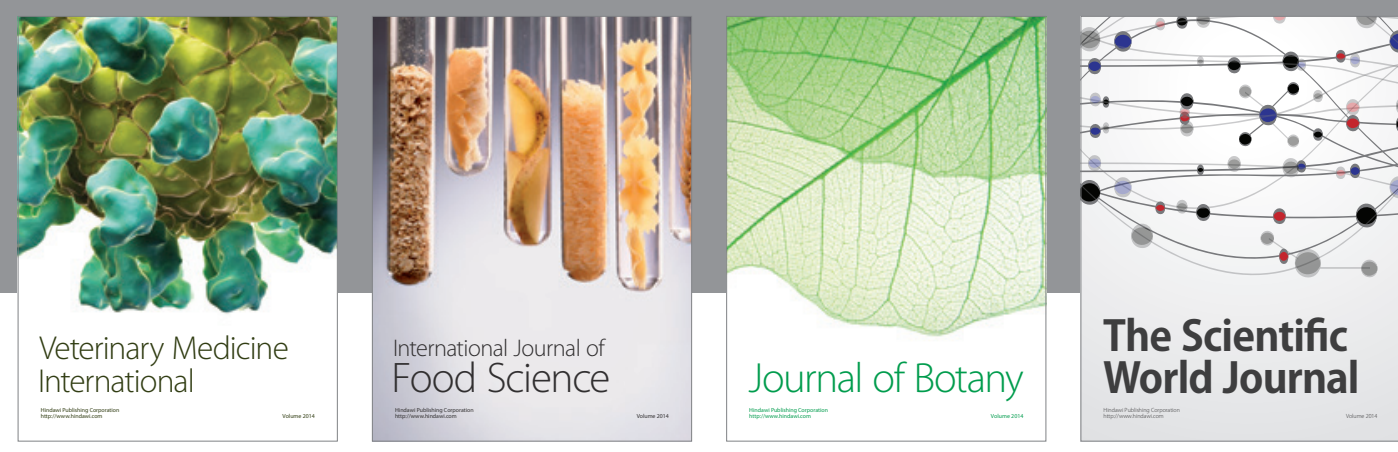

The Scientific

\section{World Journal}

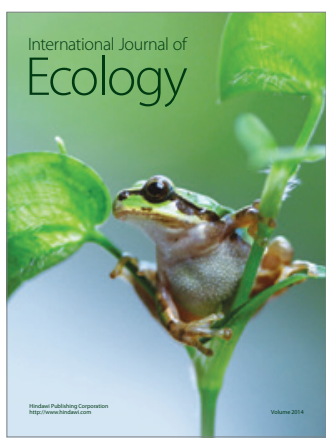

\section{Hindawi}

Submit your manuscripts at

http://www.hindawi.com
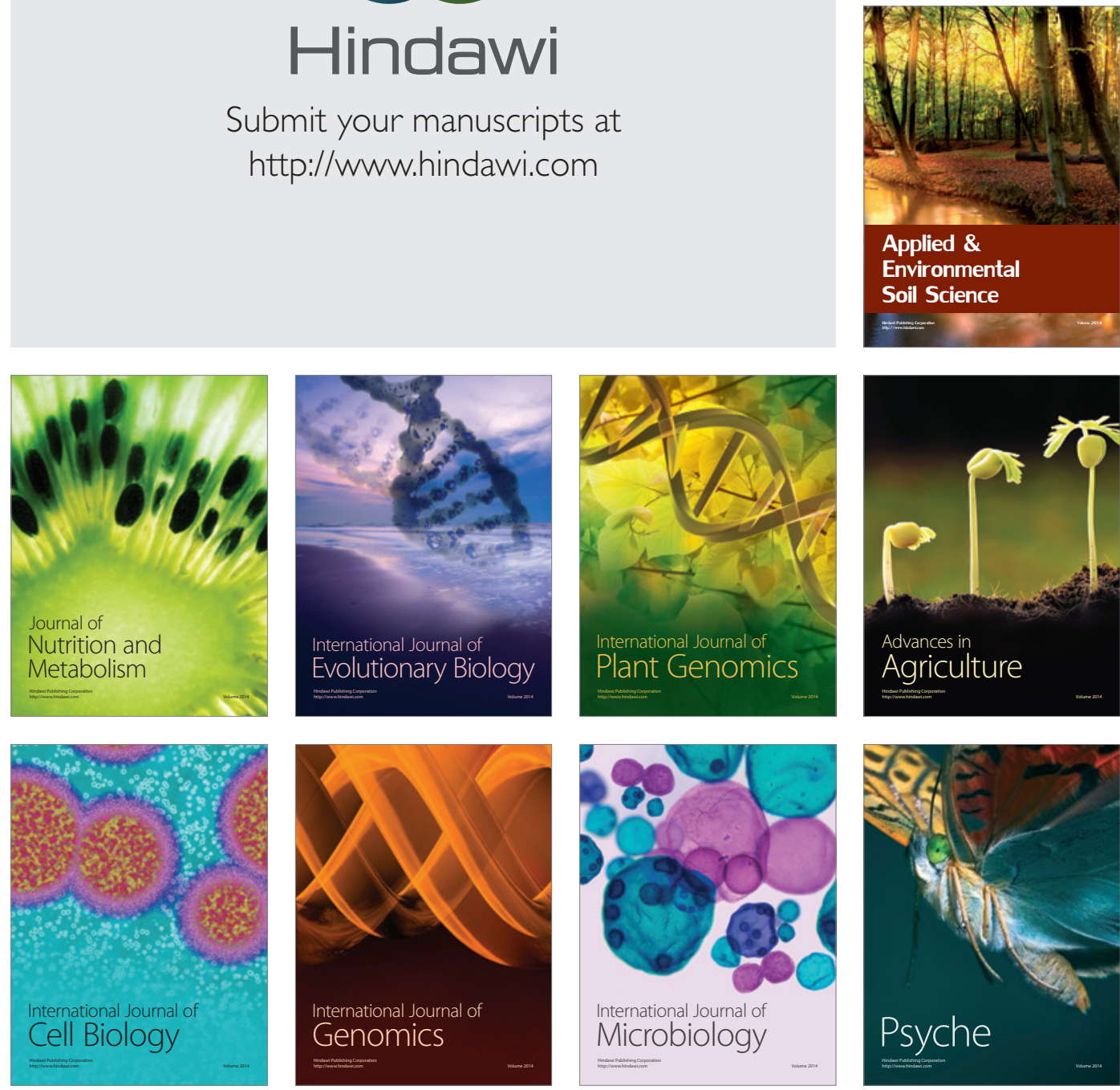
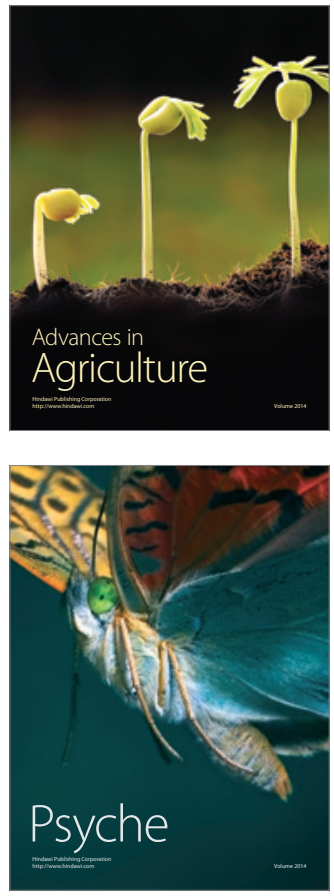